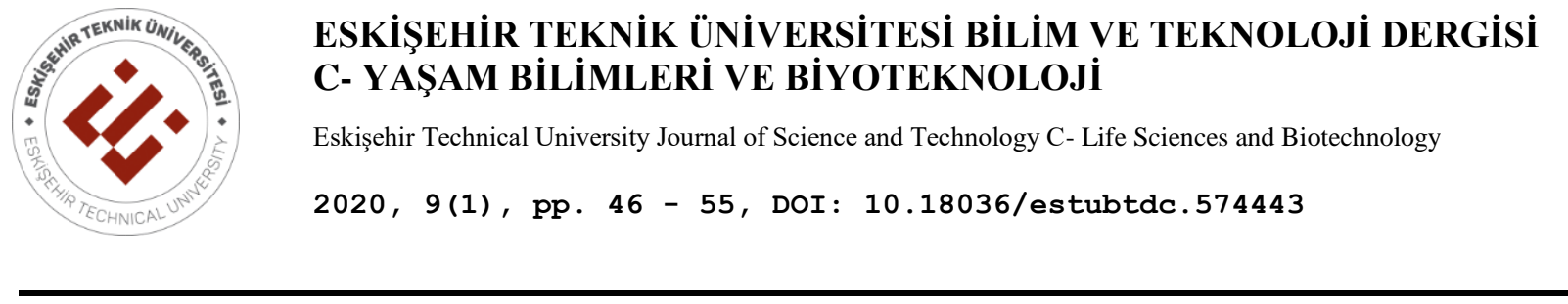

\title{
NEW RECORDS OF GEOMETRID MOTHS (LEPIDOPTERA: GEOMETRIDAE) FROM SOUTHEAST OF TURKEY
}

\author{
Erdem SEVEN \\ Department of Gastronomy and Culinary Arts, School of Tourism and Hotel Management, Batman University, \\ 72060, Batman, Turkey
}

\begin{abstract}
On the basis of the specimens collected in 2015-2017 from southeast of Turkey, an overview is presented on faunistic and distributional points of view. Twenty three species in 4 subfamilies have been discovered for the first time from the area. Endemic and widespread species in the field are mentioned. Comparison of the species number with neighbouring provinces is given. Adults of Charissa dubitaria (Staudinger, 1892); C. onustaria (Herrich-Schäffer, [1852]); Eilicrinia cordiaria (Hübner, 1790); Eumera hoeferi Wehrli, 1934; Gnophos pseudosnelleni (Rjabov, 1964); Stueningia wolfi Hausmann, 1993; Aplocera plagiata (Linnaeus, 1758) and Docirava musculata (Staudinger, 1892) are illustrated.
\end{abstract}

Keywords: Geometrid moths, Bismil, Silvan, Diyarbakır, Turkey

\section{TÜRKIYY'NINN GÜNEYDOĞUSUNDAN YENI GEOMETRID GÜVE (LEPIDOPTERA: GEOMETRIDAE) KAYITLARI}

\begin{abstract}
ÖZET
Türkiye'nin güneydoğusunda, 2015-2017 yılları arasında toplanan örneklere dayanarak, faunistik ve dağılımsal bir genel bakış sunulmuştur. Alandan 4 altfamilya içerisinde 23 tür ilk kez keşfedilmiştir. Alandaki endemik ve yaygın türlerden bahsedilmiştir. Tür sayısının komşu illerle karşılaştırılması verilmiştir. Charissa dubitaria (Staudinger, 1892); C. onustaria (Herrich-Schäffer, [1852]); Eilicrinia cordiaria (Hübner, 1790); Eumera hoeferi Wehrli, 1934; Gnophos pseudosnelleni (Rjabov, 1964); Stueningia wolfi Hausmann, 1993; Aplocera plagiata (Linnaeus, 1758) ve Docirava musculata (Staudinger, 1892) türlerinin ergin bireyleri resmedilmiştir.
\end{abstract}

Anahtar Kelimeler: Geometrid güveleri, Bismil, Silvan, Diyarbakır, Türkiye

\section{INTRODUCTION}

The Geometridae are one of the most species-rich Lepidoptera-families. Most of the geometrids live in the tropics. The majority of the geometrid moths are nocturnal, and many species are attracted by light traps. However, some species also fly preferably at dusk. They are often small and inconspicuous in wing pattern and colours [1].

In Europe, more than 900 geometrid species are known [1] and 684 species are reported from Turkey [2]. Geometridae species in the Turkish fauna is examined in 208 genera of 6 subfamilies: Archiearinae, Orthostixinae, Geometrinae, Sterrhinae, Larentiinae and Ennominae. Although, there are some general studies on Lepidoptera order, the geometrid moths of Diyarbakır are not well known, and the number of the determined species is 41 so far [2-6]. Besides, Lepidoptera fauna of Bismil and Silvan districts are studied for the first time and, 23 geometrid moth species are new reported from Diyarbakır province.

Corresponding Author: erdem seven@hotmail.com

Received: 10.06.2019 Published:31.01.2020 
The collecting localities Silvan and Bismil districts are located in the southeast of Turkey. The northern part of Silvan consists of mountainous-natural areas and, the southern part contains agricultural land. Natural vegetation forms with oak species on the mountain slopes. And, almost all of Bismil district contains of farmland especially wheat, cotton and corn fields.

\section{MATERIAL AND METHODS}

Materials were collected from south-eastern Turkey, Diyarbakır province, Silvan and Bismil districts between in 2015-2017 years, with light traps, using UV strip led and 12 volts 7 ampere battery. The materials were sampled on the following localities: Silvan, Demirkuyu, $860 \mathrm{~m}, 38^{\circ} 10^{\prime} 47^{\prime \prime} \mathrm{N}-41^{\circ} 09^{\prime} 04^{\prime \prime} \mathrm{E}$, oak field; Silvan, Demirkuyu road, 720 m, 38 $08^{\circ} 38^{\prime \prime} \mathrm{N}-41^{\circ} 10^{\prime} 38^{\prime \prime} \mathrm{E}$, steppe area; Bismil, Arıkgöl, 525 $\mathrm{m}, 37^{\circ} 50^{\prime} 10^{\prime \prime} \mathrm{N}-40^{\circ} 51^{\prime} 25^{\prime \prime} \mathrm{E}$, riverside land.

The pictures of the specimens were photographed using with Fujifilm Finepix HS30EXR. The samples were identified primarily by the wing-patterns. Male genitalia were prepared for species that cannot be reliably identified based exclusively on the wing morphology. The preparations were carried out following by the standard procedure [7]: by boiling with potassium hydroxide $(\mathrm{KOH})$, dissecting and cleaning, and mounting in Euparal. Literature data were used for identification [1, 8-12] and distribution $[2-6,13-25]$ of the species. The moth samples are deposited in the Biology Laboratory of Batman University and in the collection of Seven.

\section{RESULTS}

\section{Faunistic and distributional accounts}

Family Geometridae Leach, 1815

Subfamily Ennominae Duponchel, 1845

Genus Charissa Curtis, 1826

Charissa dubitaria (Staudinger, 1892) (Figure 1. a)

Material examined. $2 \hat{\jmath} \hat{\partial} 10$ Silvan, Demirkuyu road, $720 \mathrm{~m}, 04 . V I .2016 ; 2 \hat{\jmath}$ Silvan, Demirkuyu, $860 \mathrm{~m}, 24$. VI.2017.

Range: Greece, Turkey, Lebanon, Armenia, Iran [2].

Distribution in Turkey: Hakkâri, Kayseri, Mardin, Mersin, Siirt, Van [2, 13, 22, 25] and Diyarbakır.

Charissa onustaria (Herrich-Schäffer, [1852]) (Figure 1. b)

Material examined. $5 \AA \widehat{\partial} 1$ ㅇ Silvan, Demirkuyu road, 720 m, 19.IV.2017.

Range: Southern Europe, Balkans, Turkey, Caucasus, Iran, Iraq, east Mediterranean [10].

Distribution in Turkey: Amasya, Antalya, Bolu, Bursa, Elazı̆g, Hatay, Mersin, Malatya, Kahramanmaraş, Ordu, Siirt, Trabzon, Van, Zonguldak [2, 13, 19, 20, 22, 25] and Diyarbakır.

Genus Chiasmia Hübner, [1823]

Chiasmia aestimaria (Hübner, [1809])

Material examined. 4 우 Silvan, Demirkuyu, 860 m, 15.VIII.2016.

Range: Southern Europe, Portugal, France, Balkans, Ukraine, south-eastern European Russia, Southwestern Germany, north Africa, Cyprus, Turkey, Transcaucasus, Caucasus, Middle East, Central Asia, Iran and Afghanistan [12].

Distribution in Turkey: Artvin, Bursa, Hakkâri, Konya, Kahramanmaraş, Muğla, Siirt, Van [2, 13, 22, 25] and Diyarbakır. 
Genus Eilicrinia Hübner, [1823]

Eilicrinia cordiaria (Hübner, 1790) (Figure 1. c)

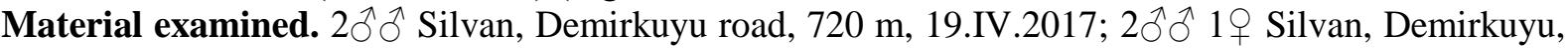
$860 \mathrm{~m}, 24$. VI.2017.

Range: Europe, Turkey, Caucasus, northern Iran and central Asia [12].

Distribution in Turkey: Adana, Adıyaman, Amasya, Ankara, Aydın, Bitlis, Bolu, Bursa, Çankırı, Edirne, Erzincan, Hakkâri, Kars, Kayseri, Kırıkkale, Konya, Malatya, Manisa, Kahramanmaraş, Niğde, Siirt, Sivas, Şırnak, Tekirdağ, Trabzon, Van [2, 15, 17, 18, 19, 22, 23, 25] and Diyarbakır.

Genus Ematurga Lederer, 1853

Ematurga atomaria (Linnaeus, 1758)

Material examined. 1 ㅇ Silvan, Demirkuyu, 860 m, 15.VIII.2016.

Range: Scandinavia, Europe, Balkans, Turkey, Caucasus, Asia $[2,10]$.

Distribution in Turkey: Amasya, Ankara, Bartın, Bilecik, Bingöl, Bitlis, Bolu, Bursa, Çanakkale, Düzce, Edirne, Mersin, İstanbul, Kastamonu, Kırıkkale, Kocaeli, Manisa, Ordu, Sakarya, Samsun, Sinop, Sivas, Tokat, Zonguldak [2, 17-20, 23, 24] and Diyarbakır.

Genus Ennomos Treitschke, 1825

Ennomos quercaria (Hübner, [1813])

Material examined. $1 \hat{\jmath} 2$ 우 Silvan, Demirkuyu, 860 m, 15.VIII.2016.

Range: Mediterranean region and south-eastern central Europe, west Balkans, northern Turkey, Caucasus region, northern Iran, Levant [12].

Distribution in Turkey: Amasya, Antalya, Bolu, Hakkâri, Hatay, Mersin, İstanbul, Konya, Samsun, Siirt, Tokat, Van $[2,14,19,22,25]$ and Diyarbakir.

Genus Eumera Staudinger, 1892

Eumera hoeferi Wehrli, 1934 (Figure 1. d)

Material examined. $2 \AA \widehat{\jmath} 1 q$ Silvan, Demirkuyu, 860 m, 24.VI.2017.

Range: Turkey, Iran, Iraq, Azerbaijan [2].

Distribution in Turkey: Hakkâri, Kayseri, Malatya, Siirt, Şırnak [2, 13, 25] and Diyarbakır.

Genus Gnophos Treitschke, 1825

Gnophos pseudosnelleni (Rjabov, 1964) (Figure 1. e)

Material examined. $3 \hat{\jmath} 1$ 우 Bismil, Arıkgöl, 525 m, 12.VII.2015.

Range: Turkey, Azerbaijan, Armenia, Iran, Turkmenistan [2].

Distribution in Turkey: Batman, Bitlis, Hakkâri, Siirt, Tunceli, Van [2, 13, 22, 25] and Diyarbakır.

Genus Selidosema Hübner, [1823]

Selidosema plumarium ([Denis \& Schiffermüller], 1775)

Material examined. $3 \widehat{\partial} \widehat{\partial} 1$ ㅇ S Silvan, Demirkuyu road, 720 m, 04.VI.2016.

Range: South and central Europe, Balkans, Turkey, Iraq [10].

Distribution in Turkey: Amasya, Bolu, Düzce, Karaman, Kahramanmaraş, Siirt, Sivas, Van [2, 19, 25] and Diyarbakır.

Genus Stueningia Hausmann, 1993 
Stueningia wolfi Hausmann, 1993 (Figure 1. f)

Material examined. $1 \widehat{\jmath}$ Silvan, Demirkuyu road, 720 m, 04.VI.2016.

Range: Turkey [2].

Distribution in Turkey: Adana, Antalya, Batman, Hakkâri, Mersin, Konya, Van [2, 13] and Diyarbakır.

Genus Stegania Guenée, [1845]

Stegania dilectaria (Hübner, 1790)

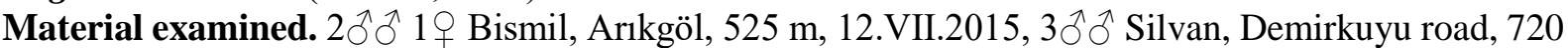
m, 04.VI.2016.

Range: Central Europe, Balkans, Turkey, Azerbaijan, Russia, China [2].

Distribution in Turkey: Adana, Bitlis, Bolu, Düzce, Edirne, İstanbul, Konya, Kırıkkale, Malatya, Kahramanmaraş, Samsun, Siirt, Tokat, Van [2, 17-19, 23, 25] and Diyarbakır.

Subfamily Larentiinae Duponchel, 1845

Genus Aplocera Stephens, 1827

Aplocera plagiata (Linnaeus, 1758) (Figure 1. g)

Material examined. $2 q q$ Bismil, Arıkgöl, $525 \mathrm{~m}, 12$.VII.2015; $3 \widehat{\jmath}$ Silvan, Demirkuyu road, $720 \mathrm{~m}$,

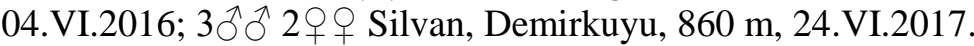

Range: Europe, south Scandinavia, Britain, Balkans, Caucasus, Transcaucasia, eastern Mediterranean, North Iran, Afghanistan, central Asia, north America [11].

Distribution in Turkey: Adana, Amasya, Ankara, Ardahan, Bitlis, Bolu, Bursa, Çanakkale, Çankırı, Düzce, Edirne, Elazı ğ, Erzincan, Gümüşhane, Hakkâri, Hatay, Mersin, İstanbul, İzmir, Kahramanmaraş, Kayseri, Kırıkkale, Konya, Malatya, Manisa, Osmaniye, Siirt, Sivas, Tokat, Trabzon, Tunceli, Van [2, 17-19, 23, 25] and Diyarbakır.

Genus Docirava Walker, [1863]

Docirava musculata (Staudinger, 1892) (Figure 1. h)

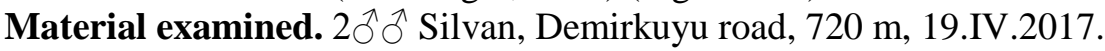

Range: Turkey, Iran, Iraq, Turkmenistan [2].

Distribution in Turkey: Amasya, Elazı̆̆, Erzurum, Giresun, Hakkâri, Malatya, Mersin, Kahramanmaraş, Kayseri, Kırıkkale, Niğde, Tunceli, Van [2] and Diyarbakır.

Genus Eupithecia Curtis, 1825

Eupithecia oblongata (Thunberg, 1784)

Material examined. $1 \delta^{\Uparrow} 1 q$ Silvan, Demirkuyu road, 720 m, 19.IV.2017.

Range: Europe, north Africa, Asia, eastern Mediterranean, Caucasus, Transcaucasia [9].

Distribution in Turkey: Adana, Amasya, Ankara, Batman, Bolu, Bursa, Çanakkale, İstanbul, Konya, Malatya, Kahramanmaraş, Kırıkkale, Ordu, Smasun, Siirt, Sivas, Van [2, 13, 19, 22, 25] and Diyarbakır.

Genus Orthonama Hübner, [1825]

Orthonama obstipata (Fabricius, 1794)

Material examined. 2 우 Bismil, Arıkgöl, 525 m, 12.VII.2015; $2 \widehat{\jmath} 1$ 우 Silvan, Demirkuyu, 860 m, 24.VI.2017. 2ðð ^ Silvan, Demirkuyu road, 720 m, 19.IV.2017.

Range: Europe, southern Scandinavia, north Africa, Turkey, Caucasus, Transcaucasia, eastern Mediterranean, Middle East, Asia, Far east Asia [11]. 
Distribution in Turkey: Adana, Amasya, Ankara, Antalya, Batman, Bitlis, Bolu, Bursa, Çanakkale, Edirne, Hakkâri, Hatay, Mersin, İstanbul, Konya, Kahramanmaraş, Kırıkkale, Osmaniye, Siirt [2, 13, 14, 17-19, 22, 25] and Diyarbakır.

Subfamily Orthostixinae Meyrick, 1892

Genus Orthostixis Hübner, [1823]

Orthostixis cribraria (Hübner, [1799])

Material examined. $7 \hat{\jmath} 5$ 우 0 Bismil, Arıkgöl, 525 m, 12.VII.2015.

Range: Southeast Europe, Balkans, Turkey, Caucasus, Transcaucasia, northern Iran, Lebanon [1].

Distribution in Turkey: Adana, Amasya, Ankara, Ardahan, Batman, Bingöl, Bitlis, Bolu, Bursa, Çanakkale, Düzce, Gümüşhane, Hatay, Mersin, Konya, Siirt, Van [2, 16, 19, 25] and Diyarbakır.

Subfamily Sterrhinae Meyrick, 1892

Genus Cyclophora Hübner, 1822

Cyclophora suppunctaria (Zeller, 1847)

Material examined. 1 đ Silvan, Demirkuyu road, 720 m, 19.IV.2017.

Range: Southern Europe, Tunisia, Turkey, Iran, Saudi Arabia [8].

Distribution in Turkey: Bolu, Hakkâri, Mersin, Konya, Kırıkkale, Siirt [2, 19, 22, 25] and Diyarbakır.

Genus Idaea Treitschke, 1825

Idaea camparia (Herrich-Schäffer, [1852])

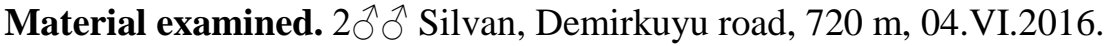

Range: Balkans, southern Italy, Turkey, Cyprus, eastern Mediterranean, Transcaucasia, Iraq, Iran, Turkmenistan, Libya?, Algeria? [8].

Distribution in Turkey: Adana, Amasya, Antalya, Bursa, Çanakkale, Edirne, Hakkâri, Hatay, Mersin, Iğdır, İzmir, Manisa, Kahramanmaraş, Ordu, Tekirdağ, Van [2, 13, 15, 17, 18, 20] and Diyarbakır.

Idaea elongaria (Rambur, 1833)

Material examined. 1ठิ Bismil, Arıkgöl, 525 m, 12.VII.2015; 1ठ Silvan, Demirkuyu, $860 \mathrm{~m}$, 24.VI.2017.

Range: Southern Europe, north Africa, Balkans, Turkey, eastern Mediterranean, Transcaucasia, northern Iran, Turkmenistan, Afghanistan, central Asia [8].

Distribution in Turkey: Adana, Antalya, Bursa, Çanakkale, Hatay, İstanbul, Kahramanmaraş, Kırıkkale, Siirt $[2,22,25]$ and Diyarbakır.

Genus Rhodometra Meyrick, 1892

Rhodometra sacraria (Linnaeus, 1767)

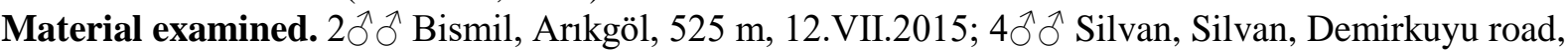

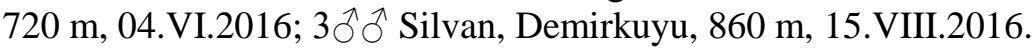

Range: Europe (from south Europe to the north), Africa, Madagascar, central Asia, central America? [8].

Distribution in Turkey: Adana, Amasya, Ankara, Antalya, Aydın, Batman; Bingöl, Bitlis, Bursa, Çanakkale, Edirne, Gaziantep, Hatay, Mersin, İstanbul, Konya, Malatya, Manisa, Kahramanmaraş, Muğla, Niğde, Ordu, Siirt, Sivas, Tekirdağ, Şanlıurfa, Van [2, 13, 15, 17, 18, 20-22, 25] and Diyarbakır.

Genus Scopula Schrank, 1802 
Scopula beckeraria (Lederer, 1853)

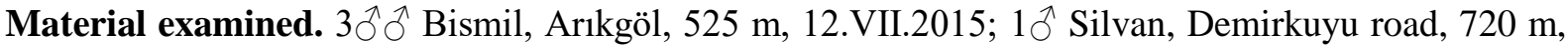
04.VI.2016.

Range: Northern Greece, Bulgaria, Macedonia, western Romania, Ukraine?, eastern Mediterranean, central Asia [8].

Distribution in Turkey: Adana, Ağrı, Amasya, Ankara, Antalya, Batman, Bitlis, Bolu, Erzincan, Erzurum, Gaziantep, Hakkâri, Kars, Kırıkkale, Konya, Mardin, Niğde, Siirt, Sivas, Şanlıurfa, Van [2, 19, 25] and Diyarbakır.

Scopula decorata ([Denis \& Schiffermüller], 1775)

Material examined. $2 \widehat{\jmath} 1 q$ Silvan, Demirkuyu, 860 m, 24.VI.2017.

Range: Europe (except for Britain and Scandinavia), Turkey, Caucasus, Transcaucasia, north Iran, Central Asia [8].

Distribution in Turkey: Afyon, Amasya, Ankara, Bitlis, Bolu, Bursa, Gaziantep, Gümüşhane, Hakkâri, Iğdır, Kayseri, Kahramanmaraş, Kırıkkale, Konya, Kütahya, Malatya, Manisa, Niğde, Osmaniye, Sivas, Tokat, Trabzon, Van [2, 16-19, 23] and Diyarbakır.

Scopula immistaria (Herrich-Schäffer, [1852])

Material examined. $3 \hat{\partial} \widehat{\partial}$ Bismil, Arıkgöl, $525 \mathrm{~m}, 12$.VII.2015; $2 \widehat{\jmath}$ Silvan, Demirkuyu, $860 \mathrm{~m}$, 24.VI.2017.

Range: Eastern Ukraine, southwest Bulgaria, southeastern Russia, Turkey, Caucasus, Transcaucasia, northern Iraq, Iran, Turkmenistan [8].

Distribution in Turkey: Ankara, Artvin, Batman, Bitlis, Elazı ̆̆, Erzincan, Erzurum, Hakkâri, Iğdır, Malatya, Kahramanmaraş, Mardin, Siirt, Sivas, Van [2, 22, 25] and Diyarbakır. 

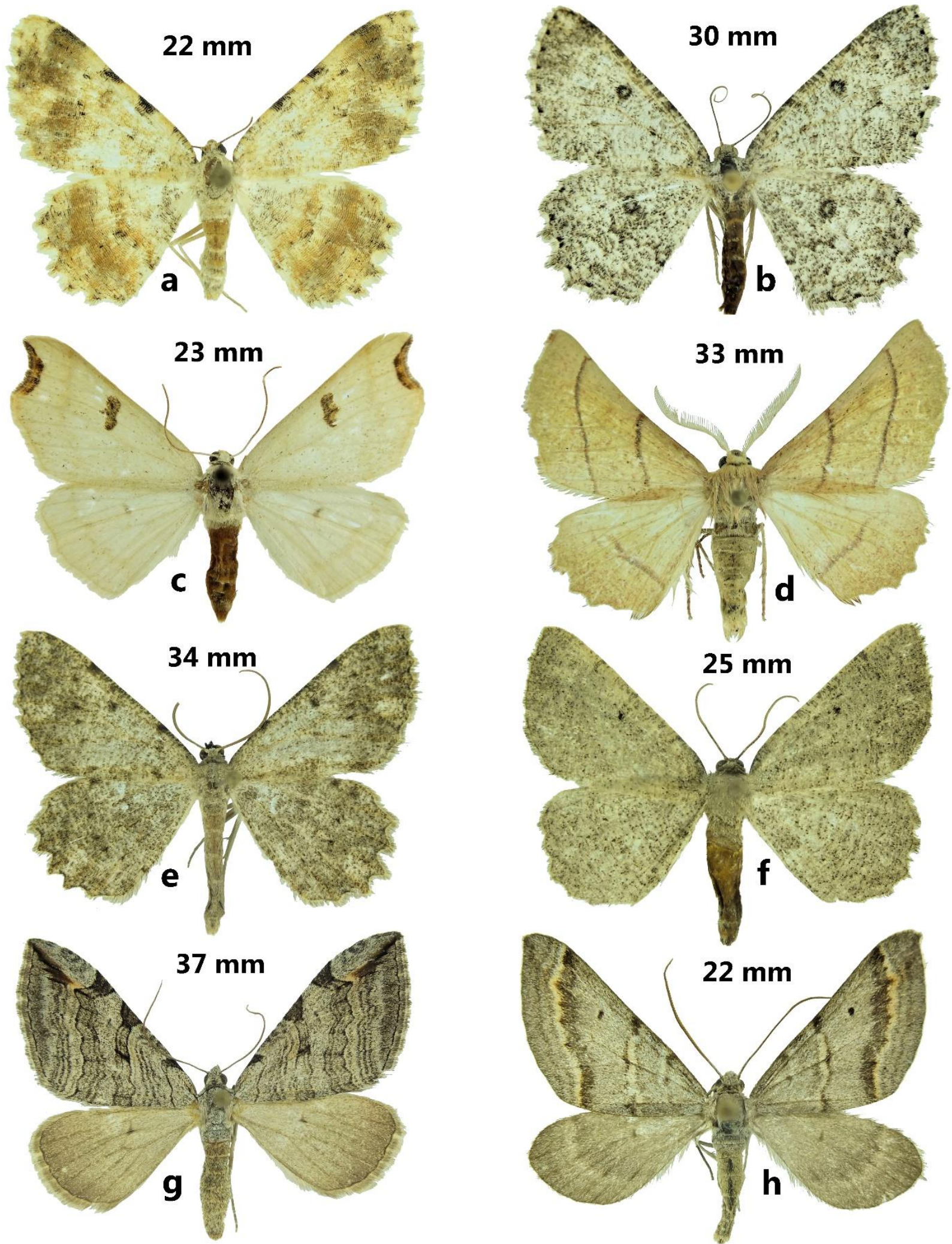

Figure 1. Adults of some species. a. Charissa dubitaria, b. Charissa onustaria, c. Eilicrinia cordiaria, d. Eumera hoeferi, e. Gnophos pseudosnelleni, f. Stueningia wolfi, g. Aplocera plagiata, h. Docirava musculata 


\section{DISCUSSION AND CONCLUSION}

Before the research, 41 species were known in 5 subfamilies of Geometridae family from Diyarbakır province. In this study, 23 species are new discovered in the 4 subfamilies: Ennominae (11), Larentiinae (4), Orthostixinae (1) and Sterrhinae (7). Ennominae subfamily contains the highest species number. Moreover, Orthostixinae subfamily, represented by 2 species in Turkey and 1 in Europe $[1,2]$, is new reported from the study area (Table 1).

Table 1. Species number of the subfamilies before and after the studies in Diyarbakır province

\begin{tabular}{lccccccc}
\hline & Desmobathrinae & Ennominae & Geometrinae & Larentiinae & Orthostixinae & Sterrhinae & Total \\
\hline $\begin{array}{l}\text { Old } \\
\text { records }\end{array}$ & 1 & 18 & 3 & 11 & - & 8 & 41 \\
\hline $\begin{array}{l}\text { New } \\
\text { records }\end{array}$ & - & 11 & - & 4 & 1 & 7 & 23 \\
\hline Total & 1 & 27 & 3 & 15 & 1 & 17 & $\mathbf{6 4}$ \\
\hline
\end{tabular}

As the geometrid moths of Diyarbakır province are compared with some nearby provinces [2, 13], the contribution of this research is clearly seen with an increase of $56 \%$. The low number of the species in Bingöl and Tunceli provinces indicate that these regions have not been studied sufficiently yet (Figure 2).

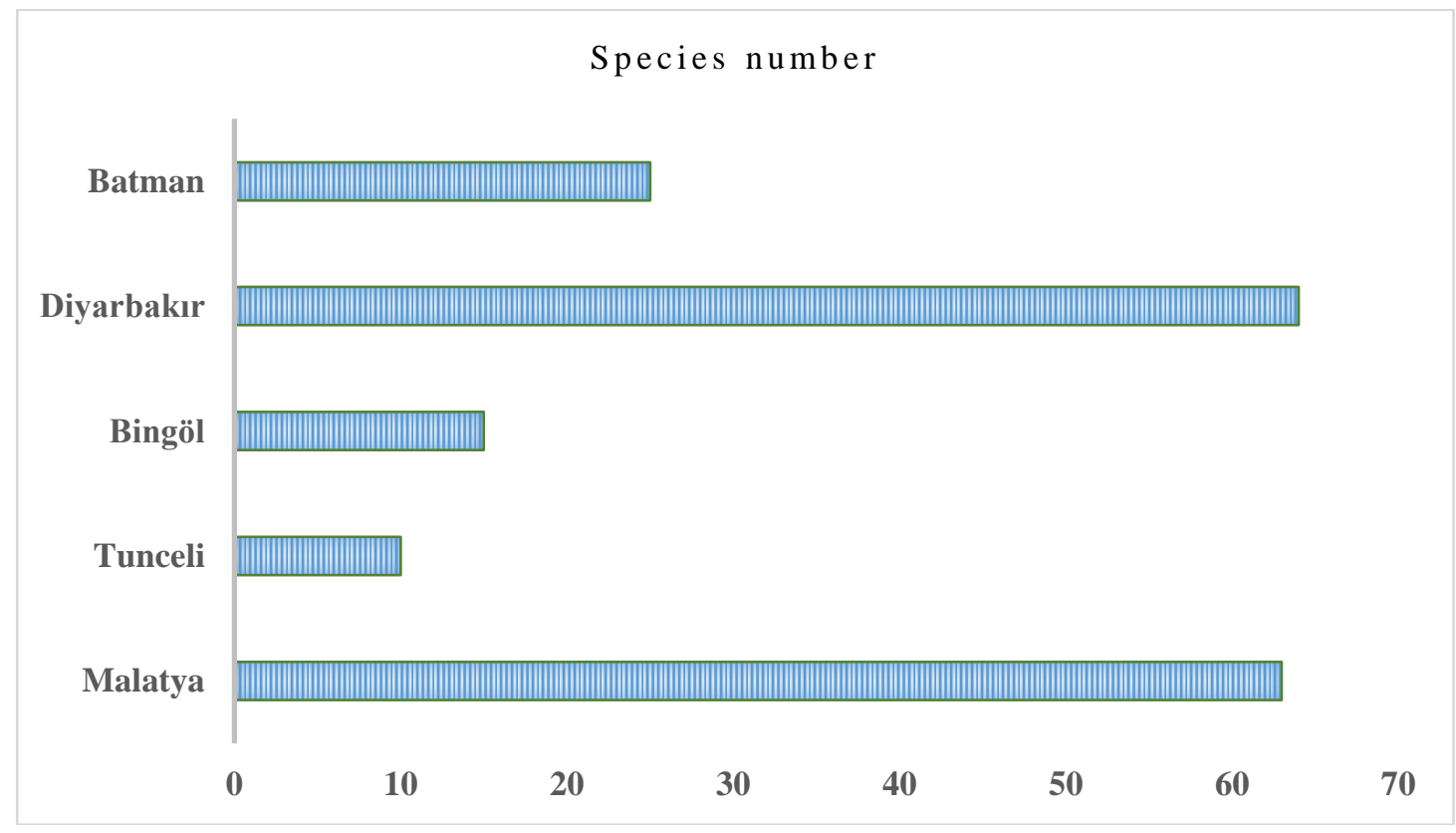

Figure 2. Comparison of the species number in Diyarbakır and some nearby provinces

Stueningia wolfi Hausmann, 1993 is an endemic species and known only from Turkey in Adana, Antalya, Batman, Hakkâri, Mersin, Konya, Van [2, 13] and Diyarbakır (new record).

Eumera hoeferi Wehrli, 1934 is known from Turkey, Iran, Iraq to Azerbaijan [2]. In Turkey, it shows a local distribution in east and south regions and, is known from Hakkâri, Kayseri, Malatya, Siirt, Şırnak $[2,25]$ and Diyarbakır (new record) provinces.

Aplocera plagiata (Linnaeus, 1758), Orthonama obstipata (Fabricius, 1794) and Rhodometra sacraria (Linnaeus, 1767) species show widespread distribution in the study area. 
Seven / Eskişehir Technical Univ. J. of Sci. and Tech. C-Life Sci. and Biotech. 9 (1)-2020

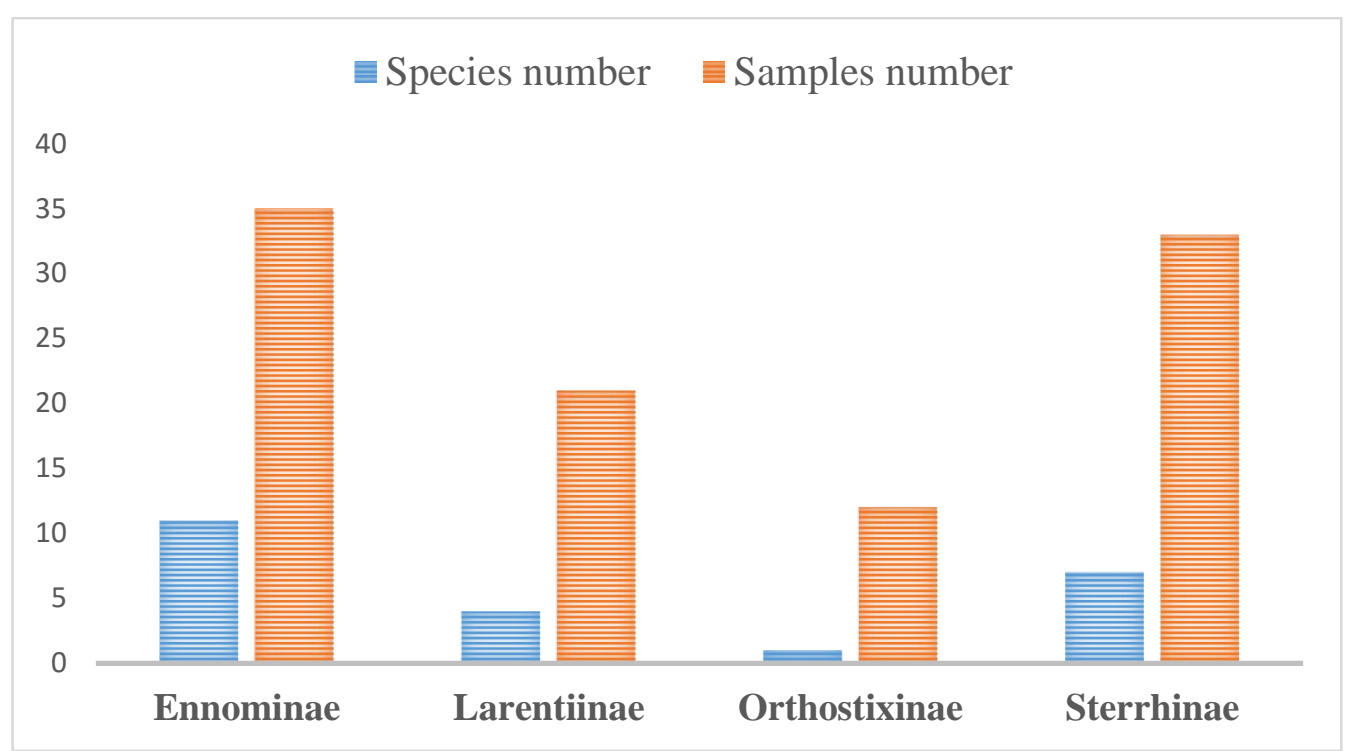

Figure 3. Comparison of the species and samples numbers according to subfamilies

As the number of collected samples in subfamilies are compared with the diagnosed species, Ennominae and Sterrhinae include the highest numbers and are proportional to the number of the samples (Figure $3)$.

The research results showed that the investigations on Lepidoptera fauna are still insufficient and are not examined thoroughly in east and southeast of Turkey. The surveys on this regions are continuing to eliminate this deficiency.

\section{REFERENCES}

[1] Hausmann A. The Geometrid Moths of Europe Vol. 1, Archiearinae, Oenochrominae, Geometrinae, Stenstrup: Apollo Books, 2001.

[2] Koçak AÖ, Kemal M. A synonymous and distributional list of the species of the Lepidoptera of Turkey. Centre for Entomological Studies, Memoirs 2018; 8: 1-487.

[3] Kemal M, Aydın M. List of the Lepidoptera of Diyarbakır Province (East Turkey). Cesa News 2008; 15: 1-6.

[4] Kemal M, Aydın M. Spring Aspects of the diurnal Lepidoptera of Kulp District with new faunal records (Diyarbakır Province, East Turkey). Cesa News 2008; 14: 1-12.

[5] Kemal M, Koçak AÖ. First annotated list of the Lepidoptera recorded in Hazro district (Diyarbakır Prov., SE Turkey). Cesa News 2015; 109: 1-91.

[6] Kemal M, Koçak AÖ, Aydın M. On the nocturnal spring moths of Kulp district (Diyarbakır Prov., SE Turkey) (Lepidoptera). Cesa News 2011; 63: 10-20.

[7] Robinson GS. The Preparation of slides of Lepidoptera genitalia with special reference to the Microlepidoptera. Entomologist's Gazette 1976; 27: 127-132.

[8] Hausmann A. The Geometrid Moths of Europe Vol. 2, Sterrhinae, Stenstrup: Apollo Books, 2004. 
[9] Mironov V. The Geometrid Moths of Europe Vol. 4, Larentiinae II, Stenstrup: Apollo Books, 2003.

[10] Leraut P. Moths of Europe. Volume 2, Geometrid moths, Verrières-le-Buisson: N.A.P. Ed., 2009.

[11] Hausmann A, Viidalepp J. The Geometrid Moths of Europe. Vol. 3, Larentiinae I, Stenstrup: Apollo Books, 2012.

[12] Skou P, Sihvonen P. The geometrid moths of Europe. Vol. 5, Ennominae I, Brill \& Leiden, 2015.

[13] Seven E. First comprehensive faunistic list on the Lepidoptera species of Batman province (Southeastern Turkey). Munis Entomology \& Zoology 2019; 14(2): 439-447.

[14] Ayberk H. Three New Geometridae (Lepidoptera) Species for The Fauna of Istanbul Belgrad Forest, Turkey. Phegea (Flemish Entomological Society of Belgium) 2010; 38: 143-148.

[15] Koçak AÖ, Seven, S. Faunistische Notizen Über Türkisch-Thrazien Lepidopteren. Miscellaneous Papers 1991; 10: 4-12.

[16] Mol T. The Marmara ve Ege Bölgeleri Ormanlarında Yaşayan Geometridae Türleri Üzerinde Araştırmalar. Istanbul University Press, Istanbul, 1977.

[17] Okyar Z, Aktaç N. Faunistic and Taxonomic Studies on the Geometridae Species of Turkish Thrace. Turkish Journal of Zoology 1999; 23(1): 99-132.

[18] Okyar Z, Mironov V. Checklist of the Geometridae of European Turkey, with New Records (Lepidoptera). Zootaxa 2008; 1789: 1-56.

[19] Özdemir M. Studies on the Geometridae fauna of the provinces Bolu and Düzce in North-West Turkey (Lepidoptera). Priamus Supplement 2007; 7: 1-154.

[20] Özdemir M. Contributions to the knowledge of Geometridae fauna (Lepidoptera) of Ordu province. Plant Protection Bulletin 2016; 56(2): 209-225.

[21] Doğanlar M, Özbek H, Ecevit O, Yüksel H. Some Lepidoptera of Eastern Anatolia. Plant Protection Bulletin 1982; 21(3): 155-172.

[22] Kemal M, Seven E. Studies on the fauna and ecology of the Geometridae (Lepidoptera) in Şirvan district (Siirt Province, SE Turkey). Priamus Supplement 2013; 29: 1-48.

[23] Can F. Geometrid moths (Lepidoptera) from the middle and eastern Black Sea Regions of Turkey. Turkish Journal of Zoolology 2008; 32: 1-8.

[24] Akbulut S, Yüksel B, Keten A. The Lepidoptera (Insecta) Fauna of Düzce Province, Turkey. Turkish Journal of Zoolology 2003; 27: 257-268.

[25] Seven E. Eco-faunistic studies on the Macroheterocera species in Şirvan district of Siirt (Lepidoptera). (Unpublished doctoral dissertation). Yüzüncü Y1l University, Van, Turkey, 2014. 